\title{
A Study of Small and Medium - Scale Enterprises (SMEs) Owners' Resources Mobilisation and Innovative Culture in South- West Nigeria
}

\author{
Abolaji Olugbenga Bukki ${ }^{1}$,Yekinni Abiodun Oguntimehin ${ }^{1}$, and 'Muyiwa Adeyemi ${ }^{1}$ \\ 1-Olabisi Onabanjo University, Ago-Iwoye, Ogun State, Nigeria, Department of Educational Management and Business Studies \\ Corresponding author contact:bukki.abolaji@oouagoiwoye.edu.ng
}

\begin{abstract}
This study examined resource mobilisation and innovative culture of small and medium-scale enterprises (SMEs) owners in South-West, Nigeria. Five research questions were raised. The study adopted the descriptive survey research design. The sample comprised one thousand, four hundred and seventeen (1417) SME owners / managers out of which one thousand, three hundred and eighty-two (1382) responded appropriately, this showed $97 \%$ response rate. Data were collected using two instruments; these are Resource Mobilisation Questionnaire $(r=0.85)$ and Innovative Culture Scale $(r=0.68)$. Data were analysed using descriptive statistics, Pearson Product Moment Correlation and Independent $t$ test. The results showed that SME owners possessed high level of resource mobilisation and innovative culture in South-West, Nigeria. Significant relationship existed between resource mobilisation and innovative culture of SME Owners' in South-West, Nigeria. Furthermore, there was significant difference in the score on resource mobilisation of SME Owners while no significant difference existed in the score on innovative culture of SME Owners in South-West, Nigeria. Based on the findings, it was recommended among others that Government agencies should create strategies to improve resource mobilisation. This, in turn, will upgrade and enhance innovation among SMEs.
\end{abstract}

Keywords: Resources, Mobilization, SMEs, Innovation and Innovative Culture

\section{$1 \quad$ Introduction}

In recent times, small and medium scale enterprises owners' innovation have turn out to be a subject of immense concerned to researchers in both the developed and developing countries. Innovation is described as the creation, progress and accomplishment of a new product, process or service, with the aim of improving competence, success or competitive advantage (Omodafe\& Nwaizugbo, 2017). It is the capacity to create or change thoughts, procedures and products. In conclusion, innovation aims to solve the problems related to the business (Ceyda and Vahap, 2017). According to Casals (2011) (as cited by Mbizi, Hove,Thondhlana and Kakava, 2013),globalization of the markets and increasing international competition force SMEs to search for new, innovative, flexible and imaginative ways to survive, therefore making it their way of life (culture).

An innovative culture is viewed as a way of life sustaining innovation (Linn \& Isabelle, 2014) since innovation is a key cost or value for people who are part of innovative culture (Dmitry, \& Polina, 2012). Rao and Weintraub (2013) (as cited by Lakiza 2018) believed that an innovative culture depends on six interrelated building blocks. These are resources, procedures, achievement, qualities, behaviour and climate. The first three blocks were seen to be more tangible and simple to measure because they are more appealing to administrators expecting to revive their firm's innovative capabilities while the other three blocks which are qualities, behaviour and climate were seen as more human-focused and intangible, and in this manner harder to quantify because they are all the more 
regularly disregarded as directors have a tendency to be less positive about exploring through these human viewpoints. The goal of any SME is to have competitive advantage or to stretch out beyond the opposition. (Obiri, Iwara, Kalu, Ezebor\& Alabi, 2018).

However, the phenomenon of innovation cannot be effectively accomplished without the diligent work of the SME owners (Gundling, 2000). They determine atmosphere and lifestyle that supports and recognizes innovation in any business (Ahmed, 1998). Accordingly, it is a must for them to have the ability to acquire or direct all resources toward the strategic objective of the enterprise and ensure that organisational functions are aligned with the external environment (Zaccaro \& Klimoski, 2001 in Maladzhi, Yan \& Makinde, 2012)

Resource mobilisationis a process of identifying the resources essential for the development, implementation and continuation of works for achieving the firms'mission. In real terms, Resource mobilisationmeans expansion of relations with the resource providers, the skills, knowledge and capacity for proper use of resources. Resource mobilisationis a means to the end, the end being the satisfaction of the company's vision; a team effort that involves the firm's commitment to resource mobilization, acceptance for the need to raise resources and institutionalization of resource mobilisationpolicies and budget allocation to priorities (East African Community Manual, 2014).

Resource mobilisationcan be defined as a management process of identifying individuals who share the values of your organization and take steps to manage this relationship. Resource mobilisationis often wrongly considered as fundraising. In fact, fundraising as a component of the resource mobilisation, refers to a variety of resources. Therefore, resource mobilisationinvolves the improvement of ability or capacity to "steal the donors' heart" by winning them over to the cause of the organisation (IDRC, 2013).

Resource mobilisationis giving people the opportunity to give. It is the process whereby resources are exchanged from the individuals who can provide for the individuals who want to receive. It is the enabler of the activity that not only satisfies the need, but also satisfies the giver that the resources have been carefully and adequately utilised. Resource mobilisationis all about building relationships with donors - whether individuals or major corporations (Kipchumba, Zhimin \& Chelagat, 2013).

In general, availability of resources is emphatically identified with innovation since resources are needed to develop ideas. Organisations wishing to create an innovative culture need to recognize and create individuals who are themselves innovative, and to ensure managers and leaders are prepared to help them by offering self-governance, resources, a shared vision, guidance and criticism. Many organisations start to foster innovation through idea-capture and suggestion schemes (Patterson, Kerrin \& Gatto-Roissard, 2012).

Innovation has become one of the most critical issues facing SMEs today; mainly because it is crucial to the development of new products which enhances companies'rapid growth and profit margins. Similarly, considerations are being given to the importance of resource mobilisationof SMEs.Despite a number of research on the innovation of business enterprises, there is still rareness of empirical studies on the resource mobilisation and innovative culture of SMEs in Nigeria. The main objective of this study is to examine resources mobilisation and innovative culture of SME owners in South-West, Nigeria. The specific objectives of the study are to:

- assess the level of SME owners' resource mobilisationand innovative culture;

- investigate the relationship between resource mobilisationand innovative culture of SME owners;

- investigate the difference between small and medium scale entreprises' resource mobilisationin south-west, Nigeria, and

- investigate the difference between small and medium scale entreprises' innovative culture in southwest, Nigeria. 


\section{Research Questions}

To achieve the objectives of the study, the following research questions are raised:

1. What is the level of resource mobilisation of SME Ownersin South-West, Nigeria?

2. What is the level of innovative culture of SME Ownersin South-West, Nigeria?

3. Is there any significant relationship between SME Owners' resource mobilisation and innovative culture in South-West, Nigeria?

4. Is there any significant difference between small and medium scale entreprises' scoreson resource mobilisationin South-West, Nigeria?

5. Is there any significant difference between small and medium scale entreprises' scores on Innovative Culture in South-West, Nigeria?

\section{Methodology}

The study adopted the descriptive survey research design. The target population consisted of 26,744 business owners/managers of registered SMEs in South-West, Nigeria. (National Bureau of Statistics, 2013).1,417 business owners/managers were selected for the study (this comprises of 1257 small-scale enterprises owners and 160 medium-scale enterprises owners). To select the sample, SMEs were stratified based on the existing State levels and from each stratum, 5\% of small and 10\% of medium-scale enterprises were selected using random sampling technique. The number of the selected SMEs and managers/ owners from each of the six (6) State areas are presented in Table 1:

Table 1. Sample Distribution of each State

\begin{tabular}{|c|c|c|c|c|c|}
\hline States & $\begin{array}{c}\text { Total of } \\
\text { SMEs in } \\
\text { each States }\end{array}$ & $\begin{array}{c}\text { Total of Small } \\
\text { Enterprises }\end{array}$ & $\begin{array}{c}5 \% \text { of Small } \\
\text { Enterprises } \\
\text { Sampled } \\
\end{array}$ & $\begin{array}{c}\text { Total of } \\
\text { Medium-scale } \\
\text { Enterprises }\end{array}$ & $\begin{array}{c}10 \% \text { of Medium- } \\
\text { scale Enterprises } \\
\text { Sampled }\end{array}$ \\
\hline Lagos & 11,663 & 11,044 & 552 & 619 & 62 \\
\hline Ogun & 1,794 & 1,690 & 85 & 104 & 10 \\
\hline Oyо & 7,987 & 7,468 & 373 & 519 & 52 \\
\hline Ondo & 1,999 & 1,805 & 90 & 194 & 20 \\
\hline Osun & 2,272 & 2,247 & 112 & 25 & 04 \\
\hline Ekiti & 1,029 & 903 & 45 & 126 & 12 \\
\hline Total & 26,744 & 25,157 & 1,257 & 1,587 & 160 \\
\hline
\end{tabular}

\section{Instrumentation}

Two instruments were used for this study, namely:

\section{Resource Mobilisation Questionnaire (RMQ)}

Resource mobilisation was measured using resource mobilisation questionnaire (RMQ) developed by Bukki (2018) which was designed to assess biographical information, identification of resources, resource providers and mechanisms. The questionnaire contains forty (40) items of Likert scale type ranging "1 strongly disagree", " 2 disagree", " 3 agree", " 4 strongly agree". To test the reliability of the scale, a test-retest with two weeks interval was carried out. The instrument was administered on thirty 
(30) business owners of small and medium-scale enterprises in Benin metropolis, in Edo State, Nigeria. The instrument yielded 0.85 coefficient (Cronbach alpha value) which is strong enough to justify the use of the instrument.

\section{Innovative Culture Scale}

The scale was adopted from Abdi and Ali (2013). Five-point Likert scales were developed to measure the enterprises level of innovative culture. Thus, the reliability test conducted to determine the internal consistency of the measures used, the variables have Cronbach Alpha values of more than 0.7 (Administrative Innovation 0.860, Technical Innovation 0.768 and Innovation Strategy 0.767) which makes all variables accepted, internally consistent and the scale deemed reliable for further analysis (Abdi \& Ali, 2013). To revalidate the scale, a test-retest with two weeks interval was carried out. The instrument was administered on thirty (30) business owners of SMEs in Benin metropolis who were not part of the main study. This yielded a coefficient of 0.68 Cronbach alpha value.

The data for this study were collected by the researcher with the help of six (06) research assistants from each of the six states in the south-west, Nigeria. The administration of the instruments was carried out within a time-span of twenty-four (24) weeks. One thousand, four hundred and seventeen $(1,417)$ questionnaires were administered to business owner/managers of SMEs in South-West, Nigeria out of which One thousand, three hundred and eighty-two (1382) questionnaires were returned, this showed $96.8 \%$ response rate. The statistical analysis that was used for answering the raised research questions were analysed with the use of Descriptive statistics, PPMC and Independent t-test analysis at $0.05 \%$ level of significance.

\section{Results}

\section{Research Question 1: What is the level of resource mobilisation of SME owners?}

Data collected on resource mobilisation were used to classify respondents'score into two groups namely: low (below the average mean score) and high (average and above the average mean score). Based on this classification, the data on respondents' responses on resource mobilisationwere subjected to descriptive statistics as presented in Table 1 .

Table 2. Descriptive Statistics of SME owners' Resource Mobilisation

\begin{tabular}{|l|l|l|l|l|}
\hline Resource Mobilisation & N & \% & Mean & Std. Deviation \\
\hline Low & 685 & 49.6 & 102.724 & 15.876 \\
\hline High & 697 & 50.4 & 133.324 & 10.724 \\
\hline Total & 1382 & 100 & 118.157 & 20.422 \\
\hline
\end{tabular}

Table 2 indicated that $49.6 \%$ (with a mean score of 102.724 and a standard deviation of 15.876) of the SME owners/managers possessed low level of resource mobilisation and 50.4\% (with a mean score of 133.324 and a standard deviation of 10.724) possessed high level of resource mobilisation. The implication of this is that substantial number of the SME owners/ managers who participated in this study possessed high level of resource mobilisation.

\section{Research Question 2: What is the level of SME owners' innovative culture?}


Data collected on innovative culture were used to classify respondents'scores into two groups namely: low (below the average mean score) and high (average and above the average mean score). Based on this classification, the data on respondents' responses on innovative culture were subjected to descriptive statistics as presented in Table 3.

Table 3. Descriptive Statistics of SME owners' Innovative Culture

\begin{tabular}{|l|l|l|l|l|}
\hline Innovative culture & $\mathrm{N}$ & $\%$ & Mean & Std. Deviation \\
\hline Low & 570 & 41.2 & 55.284 & 11.492 \\
\hline High & 812 & 58.8 & 71.878 & 5.692 \\
\hline Total & 1382 & 100 & 65.034 & 11.841 \\
\hline
\end{tabular}

Table 3 indicated that $41.2 \%$ (with a mean score of 55.284 and a standard deviation of 11.492) of the SME owners / managers possessed low level of innovative culture and 58.8\% (with a mean score of 71.878 and a standard deviation of 5.692) possessed high level of innovative culture. The implication of this is that majority of the SME owners / managers who participated in this study possessed high level of innovative culture.

Research Question 3: Is there any significant relationship between resource mobilization and innovative culture of SMEs in South-West, Nigeria?

Table 4.Correlation matrix of Resource mobilisation and Innovative Culture of SMEs

\begin{tabular}{|c|c|c|}
\hline Variables & RM & IC \\
\hline Resource Mobilisation(RM) & 1 & 1 \\
\hline Innovative Culture (IC) & $0.405^{* *}$ & 65.034 \\
\hline Mean & 118.157 & 11.841 \\
\hline Standard Deviation & 20.422 & Correlation is significant at the 0.01 level (2-tailed).
\end{tabular}

The results in Table 4 revealed that there is a positive relationship between resource mobilisation and innovative culture of SMEs $\left(\mathrm{r}_{(1382)}=.405 ; \mathrm{p}<0.05\right)$.

Research Question4: Is there any significant difference between small and medium scale entreprises' scoreson resource mobilisation in South-West, Nigeria?

Table 5. Comparison of small and medium scale entreprises' scores on resource mobilisation

\begin{tabular}{|l|l|l|l|l|l|l|l|}
\hline Resource mobilisation & N & Mean & SD & df & t & Sig & Remark \\
\hline Small scale enterprises & 1237 & 118.62 & 20.54 & 1380 & 2.466 & .014 & Significant \\
\cline { 1 - 5 } $\begin{array}{l}\text { Medium scale } \\
\text { enterprises }\end{array}$ & 145 & 114.20 & 18.92 & & & \\
\hline \multicolumn{78}{|c|}{ Significant at the 0.05 level } \\
\hline
\end{tabular}

Table 5 showed that there is significant difference between small and medium scale entreprises' scoreson resource mobilisation $(\mathrm{t}=2.466 ; \mathrm{P}<0.05)$. 


\section{Research Question5: Is there any significant difference between small and medium scale} entreprises' scores on Innovative Culture in South-West, Nigeria?

Table 6. Comparison of small and medium scale entreprises' scores on Innovative Culture

\begin{tabular}{|l|l|l|l|l|l|l|l|}
\hline Innovative Culture & $\mathrm{N}$ & Mean & SD & Df & t & Sig & Remark \\
\hline Small scale enterprises & 1237 & 65.16 & 11.86 & 1380 & 1.178 & .239 & Not significant \\
\cline { 1 - 4 } & 145 & 63.93 & 11.62 & & & & \\
\hline
\end{tabular}

Table 6 showed that there is no significant difference between small and medium scale entreprises' scores on Innovative Culture in South-West, Nigeria $(t=0.755 ; \mathrm{P}>0.05)$.

\section{Discussions}

Research question one result revealed that substantial number of the SME owners/ managers who participated in this study possessed high level of resource mobilisation. It is not surprising that they possessed a high level of resource mobilisation since they considered assets to be what can encourage them to have upper hand in the market. This additionally demonstrated that for SME owners to manage and oversee their business effectively, resources will play unique jobs among the existence cycle of SME. This result was in consonance with the findings of O'Cass and Sok (2014) who found that changes in markets and competition require firms to maximise the acquisition of high levels of both resources and capabilities, in order to compete successfully and achieve growth. This result was not in alignment with the findings of Nowacki and Staniewski (2012) who revealed that SMEs had less access to resources.

Research question two result revealed that majority of the SME owners / managers who participated in this study possessed high level of innovative culture. The explanation behind this outcome could be on the grounds that SMEs were especially quick to find how they can contend with bigger organizations by ending up more innovative and imaginative than their bigger competitors. These results corroborated the findings of Nordman and Tolstoy (2016) who indicated that SMEs need a relatively higher level of innovative culture. According to OECD, (2012) reports there is a high level of innovation activity taking place among small firms that may not be fast-growth or associated with traditional high-technology sectors. Laegreid, Roness and Verhoest (2009) also discovered that state agencies in Norway and Flanders report a high level of innovative culture in their own agencies and also assess their ability to develop innovative products and services fairly highly.

Research question three result revealed that there is a positive relationship between resource mobilisation and innovative culture of SMEs. This corroborated the findings of Terziovski (2003) who discovered that small manufacturing companies were more likely to improve their chances of achieving business excellence through resources mobilisation. This result corroborated the findings of Hemert (2012) who revealed that there was a causal connection between a firm's resources and its innovation performance. This result also corroborated the assertion of Watjatrakul (2005) in Rajput and Kalhoro (2014) that resources both strategic and non strategic are important for the success of a firm as strategic resources enable organizations to sustain competitive advantage. If the resources are valuable, rare, imperfectly imitable and non-substitutable, its' mobilisation would be considered strategic to the firm. 
Research question four result revealed that there is significant difference in the score on resource mobilization of small and medium scale entreprises in South-West, Nigeria. This could be because of their size and few resource commitments are required for small size enterprises. Another possible reason why significant difference existed in their response could be because both small and mediumscale enterprises are conscious that the more the companies possess the desirable resources, the more it may innovate in product or service that will automatically turn into a culture. This result corroborated the findings of Nowacki and Staniewski (2012) that small enterprises have less access to resources than their medium entreprises counterparts. Ameyaw, Korang, Twum and Asante (2016) also discovered that Small scale enterprises require lower start-up capital and resources as compared to the larger companies.

Research question five result revealed that there is no significant difference in the score on innovative culture of small and medium scale entreprises in South-West, Nigeria. A cause for this result could be because SMEs were always interested in developing innovative and resourceful ideas that can make them contend and outperform their larger competitors. This lends support from the findings of Staniewski, Nowacki and Awruk (2016) which indicated that there was no dramatic difference between small and medium companies as far as innovativeness is concerned (there is no discrepancy between the quality and significance of the innovations they create). This result contradicted the findings of Gray,Densten and Sarros (2003) who revealed that small organiations were perceived to be significantly more supportive, competitive, innovative, and performance-oriented than medium-sized organisations. Reboud, Mazzarand Soutar (2014)findings also showed that the level of innovative activity amongst SMEs were not significantly different.

\section{$5 \quad$ Conclusion and Recommendations}

Based on the findings of this study, it can be concluded that SME owners possessed high level of resource mobilisation and innovative culture in South-West, Nigeria. Also, there was significant relationship between SME Owners' resource mobilisation and innovative culture in South-West, Nigeria. Furthermore, there was significant difference in the score on resource mobilisation of SME Owners while no significant difference existed in the score on innovative culture of SME Owners in South-West, Nigeria. Based on these findings, it was recommended among others that Government agencies should create strategies to improve resource mobilisation. This, in turn, will promote and boost innovation among SMEs. The government should discharge assets for the SME's or build up a bank for those engaged with SME's to depend on. It is suggested that the coverage and scope of the study should be expanded to include more states and respondents.

\section{References}

Abdi, A. M. \& Ali, A. Y. S. (2013). Innovation and business performance in telecommunication industry in Sub-Sahara African context: Case of Somalia. Asian Journal of Management Sciences and Education, 2(4), 53-67.

Ahmed P. K. (1998). Culture and climate for innovation . European Journal of Innovation Management, 1(1), 30-37.

Ameyaw, B., Korang, J. A., Twum, E. T. \& Asante, I. O (2016).Tax policy, SMES compliance, perception and growth relationship in Ghana: An empirical analysis. British Journal of 
Economics, Management and Trade, 11(2): 1-11, 2016, retrieved from www.sciencedomain.org on 1st Dec.,2017

Bukki, A. O. (2018). Resource Mobilisation, Networking capabilities and Entrepreneurial initiatives as drives of innovative culture of SMEs owners in South-West, Nigeria (Doctoral Thesis) Olabisi Onabanjo University, Ago-Iwoye, Nigeria.

Casals, F. E. (2011). The SME Co-operation Framework: a Multi-method Secondary Research Approach to SME Collaboration. 2010 International Conference on E-business, Management and Economics IPEDR vol.3. IACSITPress, Hong Kong.

Ceyda U.,\& Vahap, T. (2017). Designing open innovation based product development process for SMEs using mobile technologies, EBEEC Conference Proceedings, The Economies of Balkan and Eastern Europe Countries in the Changed World, KnE Social Sciences, (pp 307-318).

Dmitry M. \& Polina K. (2012). Power of innovative culture within organizations. (Master's Thesis). Linnaeus University, Kalmar.

East African Community (2014). Draft EAC Resources MobilisationManual. East Africa.

Gray, J. H., Densten, I. L. \& Sarros, J. C. (2003). Size matters: Organisational culture in small, medium-scale $\quad$ and large Australian organisations. Journal of Small Business and Entrepreneurship, $17(1)$ Canadian Council for Small Business and Entrepreneurship ISSN: 0827-6331 Retrieved September 4, 2017, from http://www.freepatentonline.com

Gundling, E. (2000). The 3M way to innovation, Tokyo, Kodansha International.

Hemert, P. V. (2012). The influence of innovation sources and networks on the performance of Dutch SMEs. Netherlands. Print Partners Ipskamp, Business and Science Park.

International Development Research Centre (2013).Module for resource mobilization and management for research. Retrieved September 5, 2017, from http://www.idrc.ca.

Kipchumba, S. K., Zhimin, L. \& Chelagat, R. (2013). A Study on the Sources of Resources and Capacity Building in Resource Mobilization: Case of Private Chartered Universities in Nakuru Town, Kenya. Journal of International Education and Leadership, 3(2), 1-18. Retrieved on 17 June, 2018 from http://www.jielusa.org.

Laegreid, P. Roness, P. G., \& Verhoest, K. (2009). Explaining innovative culture and behaviour of state agencies. Paper presented at the EGPA Study Group on Governance of Public Sector Organizations, EGPA Annual Conference, Malta 2-5 September 2009.

Lakiza, V. (2018). Relationships between Performance Measurement Systems, Intrapreneurial Culture and Innovation Capabilities: A Longitudinal Field Case Study. (MSc Thesis), Universite de Montreal.

Linn B. \& Isabelle L. (2014). Culture as a Driver of Innovation Performance. A case study at the ASSA ABLOY Group(Master'sthesis).Royal Institute of Technology in Stockholm, Sweden. 
Maladzhi, W. R., Yan, B. \& Makinde, O. D. (2012). The impact of innovative leadership on organisational culture within South African small and medium-scale enterprises in the Western Cape, South Africa. African Journal of Business Management, 6(39), 10438-10444, Retrieved September 5, 2017, from http://www.academicjournals.org/AJBM.

Mbizi, R., Hove, L., Thondhlana, A. \& Kakava, N. (2013). Innovation in SMEs: A review of its role to organisational performance and SMEs operations sustainability. Interdisciplinary Journal of Contemporary Research in Business, 4(11), 370-389.

National Bureau of Statistics (2013). SMEDAN and National Bureau of Statistics Collaborative Survey: Selected Findings.

https://www.smedan.gov.ng/images/PDF/2013-MSME-Survey-Summary-Report.pdf

Nordman, E. R \& Tolstoy, D. (2016).The impact of opportunity connectedness on innovation in SMEs' foreign-market relationships. Technovation,57-58,47-57.

Nowacki, R., \& Staniewski, M. (2012). Innovation in the management of SMEs in the service sector in Poland. Amfiteatru Economic, 14, 755-773.

O'Cass, A. \& Sok, P. (2014). The role of intellectual resources, product innovation capability, reputational resources and marketing capability combinations in firm growth. International Small Business Journal, 32(8) 996 -1018. Retrieved on 1Dec, 2017 from http//www. isb.sagepub.com

Obiri J., Iwara N., Kalu, J. C., Ezebor, O. \& Alabi, I. (2018). Creativity and Innovation Culture: A Prerequisite for Sustaining Competitive Advantage in SMES. Covenant Journal of Entrepreneurship (CJoE) 2(1), 50-59.

OECD (2012). Gazelle rate, in entrepreneurship at a glance 2012, Paris, Organisation for Economic Co-operation and Development (OECD).

Omodafe, U. P. \& Nwaizugbo, I. C. (2017). Innovative marketing and Performance of selected SMEs in Delta State Nigeria. International Journal of Small Business and Entrepreneurship Research, 5(3), 1-18.

Patterson,F., Kerrin, M. \& Gatto-Roissard, G. (2012). Characteristics and behaviours of innovative people in organisations. Retrieved September 5, 2017, from http;//www.nesta.org.uk/library/documents/characteristics-inno-orgs-interim-report.pdf.

Rajput, A. A. \& Kalhoro, S. H. (2014). The impact of macro factors entrepreneur, innovation and opportunity on entrepreneurial success of SMEs. Middle-East Journal of Scientific Research, 20 (2), 149-161.

Rao, J., \& Weintraub, J. 2013. How Innovative Is Your Company's Culture? MIT Sloan Management Review, 54(3): 9.

Reboud, S., Mazzarol, T. \& Soutar, G. (2014). Low-tech vs high-tech entrepreneurship: A study in France and Australia. Journal of Innovation Economics \& Management,2 (14), 121-141. Retrieved from https://www.cairn.info/revue-journal-of-innovation-economics-2014-2-page121.htm on 10th December, 2017. 
Staniewski, M. W., Nowacki, R. \& Awruk, K. (2016).Entrepreneurship and innovativeness of small and medium-scale construction enterprises.International Entrepreneurship Managment Journal, 12 (3), 861-877. Retrieved September 5, 2017, from https://doi.org/10.1007/s11365-016-0385-8.

Terziovski, M. (2003). The relationship between networking practices and business excellence: A study of small to medium-scale enterprises (SMEs), Measuring Business Excellence, 7(2), 7892.

Watjatrakul, B. (2005). Determinants of IS sourcing decisions: A comparative study of transaction cost theory versus resource-based view. Journal of Strategic information systems, 14, 389415 .

Zaccaro SJ, Klimoski RJ (2001). The nature of organisational leadership: An introduction. In S. J. Zaccaro \& R. J. Klimoski (Eds.), The nature of organisational Leadership (pp. 3-41). San Francisco, CA: Jossey-Bass. 